\title{
The Sequencing of the Insulin-like Growth Factor 1 and Fibulin 5 Gene Variants in the Pre and Post-menopausal Women with Stress Urinary Incontinence
}

\author{
(D) Halime Hanım Pençe1, (D) Hani Alsaadoni22, (D) Burcu Çaykara22, (1) Sadrettin Pençe2, (D) Emin Özbek³ \\ 1 University of Health Sciences, Hamidiye Faculty of Medicine, Department of Medical Biochemistry, Istanbul, Turkey \\ 2 istanbul University, Aziz Sancar Institute of Experimental Medicine (ASDETAE), Department of Molecular Medicine, istanbul, Turkey \\ 3istanbul University Cerrahpaşa Faculty of Medicine, Department of Urology, Istanbul, Turkey
}

\section{Abstract}

Objective: Urinary incontinence (UI) is defined as a social problem via involuntary incontinence. Genetic variations that occur especially in muscle and connective tissue can cause the susceptibility stress type UI. We aimed to investigate the variations in insulin-like growth factor 1 and Fibulin 5 (FBLN5) genes in the pre and postmenopausal women with stress UI (SUI).

Methods: The study consisted of 4 groups: 43 premenopausal women with SUI, 30 premenopausal women without SUI, 43 postmenopausal women with SUI and 30 postmenopausal women without SUI. DNA was isolated from blood samples and sequenced with Illumina ${ }^{\circledR}$ MiSeq. The results were analyzed with SPSS22 (IBM Corp., Armonk, NY, USA) and $p$ value less than 0.05 was considered as statistically significant.

Results: The $A>G$ variant of rs6214 was found $5.26 \%(2 / 38)$ in the patient group and $0 \%(0 / 30)$ in the control group of the premenopausal group ( $p>0.05)$. This variant was found 2.44\% (1/41) in the postmenopausal SUI group ( $p>0.05)$. The FBLN5 rs929608 variant was not found in any group.

Conclusion: No significant association was found between UI and these variants.

Keywords: Urinary incontinence, rs6214, insulin-like growth factor 1, Fibulin 5

\section{INTRODUCTION}

Urinary incontinence $(\mathrm{UI})$ is defined as involuntary incontinence causing social and hygienic problems and is an important symptom of lower urinary tract dysfunction. It can cause depression and anxiety in women and affects women's family and social life significantly in terms of physical and psychological aspects (1). It was determined that some half of the elderly women had $\mathrm{UI}$ and some features related to fertility affected the development of UI (2). In a study conducted in Turkey, IU is found in $42.8 \%$ of the women andassociated with age, obesity and menopause (3). Stress UI (SUI), the most common type of $\mathrm{UI}$ in older women, is defined as involuntary loss of urine during the increase of abdominal pressure in the absence of bladder contractions (4). Various studies showed that genetic variations affect muscle and connective tissue structure leading to UI $(5,6)$. In this respect, examination of the variations in genes that may affect growth in muscle, ligament and cartilage tissue will contribute to revealing the target molecules underlying the pathology of this disease. Insulin like growth factor 1 (IGF1) plays a role in growth (7) and once synthesized, it binds to the receptor in the target cell and triggers proliferation (8). Fibulin 5 (FBLN5) gene encodes an extracellular matrix protein (9) and mutations in this gene were found associated with macular degeneration and hyperelastic skin (10). Thus, we aimed to investigate the effects of variations in the IGF1 and FBLN5 genes on stress UI in pre and postmenopausal women in our study. 


\section{METHODS}

\section{Study Groups and DNA Isolation}

The Ethical Committee of the Istanbul Faculty of Medicine, Istanbul University approved our study protocol (no: 2014/921) and informed consent were taken from the patients. Our project was supported by İstanbul University Scientific Research Unit (project no: 2181). In this study, 146 women aged 20-80 years were divided into 4 groups. Group 1: premenopausal women with SUI, Group 2: postmenopausal women with SUI, Group 3: control group as premenopausal women, Group 4: control group as postmenopausal women. Anamnesis of the patients was taken and physical examination was performed. International Urinary Incontinence Consultation Questionnaire-Short Form was filled. Patients with pure stress incontinence were included in the study. Patients with chronic illnesses such as diabetes mellitus, hypertension, patients with mixed incontinence, patients with vaginal prolapse, patients with neurogenic disease, cancer patients, patients taking chemotherapy and radiotherapy treatment were not included in the study. The whole blood samples were taken in ethylenediamine tetraacetic acid tubes and genomic DNA isolated with the use of PureLink DNA extraction kit (Invitrogen, USA) according to the manufacturer's instructions.

\section{Sequencing}

'Nextera XT DNA Library Preparation Kit' and 'NexteraXT Index Kit' were used in our study according to Nextera XT amplicon sequencing protocol. After the amount of 1ng DNA per sample was cleared, the samples were diluted with Qubit device and solutions to $0.2 \mathrm{ng} / \mathrm{\mu L}$. The samples were loaded into the $96-$ well plate with a volume of $5 \mu \mathrm{L}$ and the tagmentation step was performed with enzymatic fragmentation and adapter solutions. The tagmented DNA was subjected to polimerase chain reaction (PCR) with index primers and Nextera PCR Mastermix. Each sample were barcoded with separate index adding index sequences to the ends of tagmented DNA with 12 cycles-PCR. After the PCR stage, clean-up was performed with magnetic beads and ethanol. PCR products were quantified and normalized with Qubit. All samples were pooled with buffer solution by equalizing to $2 \mathrm{nmoL}$. Thus, all sequencing samples were collected in a single tube. The pool DNA library was first subjected to denaturation and dilution steps for loading the samples into the Ilumina MiSeq. Sequencing reaction was carried out by loading to a $600 \mu \mathrm{L}$ volume cartridge.

\section{Statistical Analysis}

SPSS software for Windows, version 22.0 (IBM Corp., Armonk, NY, USA) were used for statistical analysis. Kolmogorov-Smirnov test was used for the normality test. Mann-Whitney $\mathrm{U}$ and Fisher exact tests were used to detect the differences in the groups. P value less than 0.05 was considered as statistically significant.

\section{RESULTS}

The mean age of 43 premenopausal women with SUI was $45.53 \pm 4.1$, while the mean age of 30 premenopausal women as control group was $41.3 \pm 5.84$ and this was not statistically different between the groups $(p>0.05)$. On the other hand, the mean age of 43 postmenopausal women with SUI was $61.16 \pm 10.45$, while the mean age of 30 postmenopausal women as control group was $58.23 \pm 4.85$ and this was statistically different between the groups $(p<0.05)$. There was no significant difference between premenopausal women with SUI (2.5 \pm 1.26$)$ and control group $(2 \pm 1.36)$ when mean birth numbers were compared $(p>0.05)$. Similarly, there was not any significant difference between the mean birth numbers of postmenopausal women with SUI (3.8 \pm 2$)$ and control group ( $3 \pm 1.26)(p>0.05)$ (data not shown). Table 1 shows a comparison of IGF1 rs6214 and FBLN5 rs929608 variants between groups based on gene sequencing results. There were 86 patients in our SUI groups (43 in pre and 43 in post-menopausal women) and 60 subjects in our control groups. However, we could not reach the results of some of the samples in the sequencing stage and the exact sample numbers were given in Table 1. IGF1 rs6214 was found in premenopausal and postmenopausal women with SUI but these results were not statistically significant to the control groups $(p>0.05)$. However, FBLN5 rs929608 variation was not observed in any group.

\section{DISCUSSION}

We conducted a case-control study in the pre and postmenopausal women. The variations of IGF1 rs6214 and FBLN5

\begin{tabular}{|l|l|l|l|}
\hline \multicolumn{4}{|l}{ Table 1. Comparison of the gene sequencing results of groups } \\
\hline \multirow{4}{*}{ Variation } & \multicolumn{2}{|l|}{ Groups } & P value \\
\cline { 2 - 4 } & $\begin{array}{l}\text { Premenopausal } \\
\text { women with SUI } \\
(\mathrm{n}=38)\end{array}$ & $\begin{array}{l}\text { Premenopausal } \\
\text { women as control } \\
\text { group (n=30) }\end{array}$ & \\
\hline IGF1 rs6214 & $2(5.26 \%)$ & - & 0.308 \\
\hline FBLN5 rs929608 & - & - & - \\
\hline \multicolumn{5}{|l|}{} \\
\hline Variation & $\begin{array}{l}\text { Postmenopausal } \\
\text { women with SUI } \\
\text { (n=41) }\end{array}$ & $\begin{array}{l}\text { Postmenopausal } \\
\text { women as } \\
\text { control group } \\
\text { (n=26) }\end{array}$ & P value \\
\hline IGF1 rs6214 & 1 (2.44\%) & - & 0.612 \\
\hline FBLN5 rs929608 & - & - & - \\
\hline SUI: Stress urinary incontinence, FBLN5: Fibulin 5, IGF1: Insulin like growth factor1 \\
\hline
\end{tabular}


rs929608 was examined in the SUI. While FBLN5 rs929608 variation was not found in any group, IGF1 rs6214 variation was found in pre and post-menopausal women.

IGF1, important for protein for cell growth, differentiation and transformation in various tissues (11), plays roles in cell proliferation and apoptosis inhibition after binding to its receptor (12). It has also been reported that IGF1 stimulates fibroblast proliferation, increases collagen synthesis (13), and accelerates the growth and differentiation of striated muscle precursor cells in the human urethral sphincter (14). Furthermore, it was shown that low serum IGF1 levels were found associated with SUI (15). The IGF1 rs6214 variation is a three prime untranslated region (3'UTR/ G>A) polymorphism. Xu et al. (16) found in a meta-analysis study that rs6214 was associated with a significantly reduced risk of breast cancer under the allele, heterozygote and dominant models and pancreatic cancer under the recessive model. Another meta-analysis study found no association between rs6214 and high myopia (17). Yang et al. (18) found the carriers of rs6214 GG genotype have the risk of low appendicular skeletal muscle mass. IGF1 rs6214 variation wasalso found associated with Barrett esophagus (19) and the development of ischemic stroke (20). Because IGF1 plays a crucial role in hypothalamicpituitary-ovarian hormone-controlled metabolic processes, Zhao et al. (21) studied rs6214 on age at menarchevariation in Caucasian women and detected the association. However, we did not found the significant association between rs6214 and SUI in pre and post-menopausal women.

$F B L N 5$, a plasma glycoprotein, is encoded by the FBLN5 gene found in human chromosome $14 q 31(22,23)$ and affects cell proliferation and invasion in various diseases $(24,25)$. Mice with deficiency in the FBLN5 gene develop systemic heavy elastinopathy including genital prolapse (26). The FBLN5 gene rs929608 variation (IVS10-45 A>G) is located in intron 10 (27). Khadzhieva et al. (28) showed no association between the FBLN5 rs929608 ( $>C$ ) variation and pelvic organ prolapse. Random Forests analysis ranking is found 3 for rs929608 in prostate cancer aggressiveness and Lin et al. (29) suggested that FBLN5 gene variation can influence this disease. However, we did not find this variation in our groups.

\section{Ethics}

Ethics Committee Approval: The Ethical Committee of the Istanbul Faculty of Medicine, İstanbul University approved our study protocol (no: 2014/921).

Informed Consent: Written informed consent was obtained from each participicant of this study.
Peer-review: Externally peer-reviewed.

\section{Authorship Contributions}

Concept: H.H.P., H.A., B.C., S.P., E.Ö., Design: H.H.P., H.A., B.C.., S.P., E.Ö., Data Collection or Processing: E.Ö., Analysis or Interpretation: H.H.P., H.A., B.C.., S.P., Literature Search: H.H.P., H.A., B.C., S.P., E.Ö., Writing: HHP, HA, B.C., S.P., E.Ö.

Conflict of Interest: The authors of this study do not have any conflict of interest

Financial Disclosure: This project was supported by İstanbul University Scientific Research Unit (Project no: 2181).

\section{CONCLUSION}

In conclusion, we did not observe any association between SUI, IGF1 rs6214 and FBLN5 rs929608. This result may have been obtained due to the limited number of samples included in our study. However, this study is the first study investigating the relation between IGF1 and FBLN5 gene variants and SUI.

\section{REFERENCES}

1. Kök G, Şenel N, Akyüz A. GATA Jinekoloji Polikliniğine bașvuran 20 yaş üstü kadınların ürinerinkontinans açısından farkındalık durumlarının değerlendirilmesi. Gülhane Tıp Dergisi 2006;48:32-6.

2. Bilgili N, Akın B, Ege E, Ayaz S. Prevalence of Urinary Incontinence and Affecting Risk Factors in Women. Turkiye Klinikleri J MedSci. 2008;28:487-93.

3. Öztürk GZ, Toprak D, Basa E. The frequency and the affecting factors of urinary incontinence in women over 35 years old. SETB. 2012;46:170-6.

4. Dursun M, Otunctemur A, Ozbek E, Cakir SS, Polat EC. Impact of the transobturator tape procedure on sexual function in women with stress urinary incontinence. J Obstet Gynaecol Res 2013;39:831-5.

5. Skorupski P, Król J, Starega J, Adamiak A,Jankiewicz K, Rechberger T. An alpha-1 chain of type I collagen Sp1-binding site polymorphism in women suffering from stress urinary incontinence. Am J Obstet Gynecol 2006;194:346-50.

6. Skorupski P, Miotła P, Jankiewicz K, Rechberger T. Polymorphism of the gene encoding alpha-1 chain of collagen type I and a risk of pelvic organ prolapse--a preliminary study. Ginekol Pol 2007;78:852-5.

7. O’Neill BT, Lauritzen HP, Hirshman MF, Smyth G, Goodyear LJ, Kahn CR. Differential Role of Insulin/IGF-1 Receptor Signaling in Muscle Growth and Glucose Homeostasis. Cell Rep 2015;11:1220-35.

8. Laron Z. Laron syndrome (primary growth hormone resistance or insensitivity): the personal experience 1958-2003. J Clin Endocrinol Metab 2004;89:1031-44.

9. Kowal RC, Jolsin JM, Olson EN, Schultz RA. Assignment of fibulin-5 (FBLN5) to human chromosome $14 \mathrm{q} 31$ by in situ hybridization and radiation hybrid mapping. Cytogenet Cell Genet 1999;87:2-3.

10. Auer-Grumbach M, Weger M, Fink-Puches R, Papić L, Fröhlich E, AuerGrumbach P, et al. Fibulin-5 mutations link inherited neuropathies, agerelated macular degeneration and hyperelastic skin. Brain 2011;134:183952. 
11. Delafontaine P, Song YH, Li Y. Expression, regulation, and function of IGF1, IGF-1R, and IGF-1 binding proteins in blood vessels. Arterioscler Thromb Vasc Biol 2004;24:435-44.

12. LeRoith D. Insulin-like growth factor I receptor signaling--overlapping or redundant pathways? Endocrinology 2000;141:1287-8.

13. Martin P. Woundhealing--aimingforperfect skin regeneration. Science 1997;276:75-81

14. Sumino $\mathrm{Y}$, Hanada M, Hirata $\mathrm{Y}$, Sato F, Mimata $\mathrm{H}$. The effects of hepatocyte growth factor and insulin-like growth factor-1 on the myogenic differentiation of satellite cells in human urethral rhabdosphincter. Neurourol Urodyn 2010;29:470-5.

15. Ozbek E, Otunctemur A, Sahin S, Ozcan L, Dursun M, Polat E, et al. Low serum Insulin Like Growth Factor - 1 in patients with Stress Urinary Incontinence. Int Braz J Urol 2016;42:787-92.

16. Xu GP, Chen WX, Xie WY, Wu LF. The association between IGF1 Gene 3'-UTR polymorphisms and cancer risk: A Meta-analysis. Medicine (Baltimore) 2018;97:e13829.

17. Zhang D, Zeng G, Hu J, McCormick K, Shi Y, Gong B. Association of IGF1 polymorphism rs6214 with high myopia: A systematic review and metaanalysis. Ophthalmic Genet 2017;38:434-9.

18. Yang CW, Li TC, Li Cl, Liu CS, Lin CH, Lin WY, et al. Insulinlike Growth Factor-1 and Its Binding Protein-3 Polymorphisms Predict Circulating IGF-1 Level and Appendicular Skeletal Muscle Mass in Chinese Elderly. J Am Med Dir Assoc 2015; $16: 365-70$

19. McElholm AR, McKnight AJ, Patterson CC, Johnston BT, Hardie LJ, Murray LJ; Finbar Group.A population-based study of IGF axis polymorphisms and the esophageal inflammation, metaplasia, adenocarcinoma sequence. Gastroenterology 2010;139:204-12.e3.

20. Kim HJ, Kim SK, Park HJ, Chung JH, Chun J, Yun DH, et al. Polymorphisms of IGFI contribute to the development of ischemic stroke. Exp Ther Med 2012;3:93-8.
21. Zhao J, Xiong DH, Guo Y, Yang TL, Recker RR, Deng HW. Polymorphism in the insulin-like growth factor 1 gene is associated with age at menarche in caucasian females. Hum Reprod 2007;22:1789-94.

22. Argraves WS, Tran H, Burgess WH, Dickerson K. Fibulin is an extracellular matrix and plasma glycoprotein with repeated domain structure. J Cell Biol 1990;111:3155-64

23. Kowal RC, Jolsin JM, Olson EN, Schultz RA. Assignment of fibulin-5 (FBLN5) to human chromosome $14 q 31$ by in situ hybridization and radiation hybrid mapping. Cytogenet Cell Genet 1999;87:2-3.

24. Tu K, Dou C, Zheng X, Li C, Yang W, Yao Y, et al. Fibulin-5 inhibits hepatocellular carcinoma cell migration and invasion by down-regulating matrix metalloproteinase-7 expression. BMC Cancer 2014;14:938.

25. Shi XY, Wang L, Cao CH, Li ZY, Chen J, Li C. Effect of Fibulin-5 on cell proliferation and invasion in human gastric cancer patients. Asian Pac J Trop Med 2014;7:787-91.

26. Budatha M, Roshanravan S, Zheng Q, Weislander C, Chapman SL, Davis EC, et al. Extracellular matrix proteases contribute to progression of pelvic organ prolapse in mice and humans. J Clin Invest 2011;121:2048-59.

27. Elahi E, Kalhor R, Banihosseini SS, Torabi N, Pour-Jafari H, Houshmand M, et al. Homozygous missense mutation in fibulin- 5 in an Iranian autosomal recessive cutis laxa pedigree and associated haplotype. J Invest Dermatol 2006;126:1506-9.

28. Khadzhieva MB, Kamoeva SV, Chumachenko AG, Ivanova AV, Volodin IV, Vladimirov IS, et al. Fibulin-5 (FBLN5) gene polymorphism is associated with pelvic organ prolapse. Maturitas 2014;78:287-92.

29. Lin HY, Park H, Park J, Tsai YY. Genetic variations in angiogenesis-related genes in prostate cancer aggressiveness. In: Proceedings of the 102 nd Annual Meeting of the American Association for Cancer Research; 2011 Apr 2-6; Orlando, FL. Philadelphia (PA): AACR; Cancer Res 2011;71(8 Suppl):Abstract nr 2781. 